\title{
Allometric above-belowground biomass equations for Nothofagus pumilio (Poepp. \& Endl.) natural regeneration in the Chilean Patagonia
}

\author{
Andreas SchmidT ${ }^{1 *}$, Marcela Poulain ${ }^{1}$, Daniel KLEIN $^{1}, \operatorname{Kim}_{\mathrm{KRAUSE}^{1}}$, Karen PeÑA-Rojas ${ }^{2}$, \\ Harald SCHMIDT ${ }^{2}$, Andreas SCHULTE ${ }^{1}$ \\ ${ }^{1}$ Institut für Landschaftsökologie, Westfälische Wilhelms Universität Münster, Robert Koch Straße 26, 48149, Münster, Germany \\ ${ }^{2}$ Facultad de Ciencias Forestales, Universidad de Chile, Avenida Santa Rosa 11315, Santiago, Chile
}

Keywords: biomass equations / Nothofagus pumilio / natural regeneration / carbon storage / chronosequence

Mots-clés : équations de la biomasse / Nothofagus pumilio / régénération naturelle / stockage du carbone / chronoséquence

\begin{abstract}
- In the present study, allometric biomass equations were developed for Nothofagus pumilio natural regeneration relating foliage, stem and branches (aboveground), roots (belowground), and total biomass to basal diameter and total height, based on destructive measurements of 390 naturally regenerated seedlings and saplings.

- Basal diameter was the most important independent variable in all equations and accounted for more than $88 \%$ of the variability of the different biomass components. The addition of height as a second independent variable slightly improved the predictions.

- The best-fit biomass components equations that were based on combinations of basal diameter and height as independent variables had adjusted $R^{2}$ values between 0.80 and 0.95 and a mean percent standard error between $21.3 \%$ and $26.6 \%$.

- Based on the best-fit biomass equations and the natural regeneration development in a 14years chronosequence in forests managed under shelterwood cuts, the total biomass varied from $0.9 \mathrm{Mg} \mathrm{ha}^{-1}\left(0.5 \mathrm{Mg} \mathrm{ha}^{-1}\right.$ above and $0.4 \mathrm{Mg} \mathrm{ha}^{-1}$ belowground) for the primary forest, before the shelterwood cuts, to $19.5 \mathrm{Mg} \mathrm{ha}^{-1}$ (13.6 $\mathrm{Mg} \mathrm{ha}^{-1}$ above and $5.9 \mathrm{Mg} \mathrm{ha}^{-1}$ belowground) 14 years after the seed cut. In the same period, carbon storage varied, from $0.5 \mathrm{Mg} \mathrm{ha}^{-1}$ to $9.8 \mathrm{Mg} \mathrm{ha}^{-1}$.
\end{abstract}

Résumé - Équations allométriques pour la biomasse aérienne et souterraine pour la régénération naturelle de Nothofagus pumilio en Patagonie chilienne.

- Dans la présente étude, des équations allométriques ont été élaborées pour prédire la biomasse du feuillage, des tiges, des branches et des racines, ainsi que de la biomasse totale, à partir du diamètre à la base et de la hauteur totale dans une régénération naturelle de Nothofagus pumilio. Des mesures destructives ont été réalisées sur 390 plants régénérés naturellement et de jeunes arbres.

- Le diamètre à la base était la plus importante variable indépendante dans toutes les équations et représentait plus de $88 \%$ de la variabilité des différentes composantes de la biomasse. L'ajout de la hauteur en tant que deuxième variable indépendante, a légèrement amélioré les prédictions.

- Le meilleur ajustement des équations des composantes de la biomasse, fondées sur des combinaisons du diamètre à la base et de la hauteur comme variables indépendantes, a produit des valeurs de $R^{2}$ comprises entre 0,80 et 0,95 et un pourcentage moyen d'erreur standard compris entre $21,3 \%$ et $26,6 \%$.

- En utilisant le meilleur ajustement des équations de biomasse, nous avons établi dans le cas d'une régénération naturelle étudiée à travers une chronoséquence de 14 années dans des forêts gérées en coupes d'abri, que l'accroissement en biomasse totale a varié entre $0,9 \mathrm{Mg} \mathrm{ha}^{-1}(0,5$ pour les parties aériennes et 0,4 pour les racines) pour la forêt primaire, avant les coupes d'abri, et $19,5 \mathrm{Mg} \mathrm{ha}^{-1}(13,6$ et 5,9 , respectivement) 14 ans après la coupe d'ensemencement. Dans la même période, le stockage du carbone est passé de 0,5 à $9,8 \mathrm{Mg} \mathrm{ha}^{-1}$.

\footnotetext{
*Corresponding author: andreas.schmidt@wald-zentrum.de
} 


\section{INTRODUCTION}

Estimation of the biomass of trees at the seedling and sapling stages is used for forest fuel inventories, for assessing the potential of young stands as fibre sources, as indicators of net primary production and for assessing the stand's potential for carbon sequestration (Wagner and Ter-Mikaelian, 1999). Seedling biomass has also been demonstrated to be the best response variable to competition from surrounding vegetation for many tree species (Ter-Mikaelian and Parker, 2000). Therefore, estimates of seedling and sapling biomass can also be used to evaluate early performance of forest regeneration exposed to various management practices and to develop silvicultural guidelines to promote the growth of desired tree species (Ter-Mikaelian and Parker, 2000). Biomass estimation can be done based on a destructive sample of the trees and the weight of each component, such as stem, branches, foliage, and roots (Parresol, 2001; Zianis and Mencuccini, 2003). Direct harvesting methods for estimating biomass are labor-intensive and time-consuming (Zianis and Mencuccini, 2003). The most common procedure used to estimate tree biomass is through the use of regression equations. In these equations, the biomass of each tree component is related by regression to one or more dimension variables of the standing tree (Parresol, 1999; Verwijst, 1991; Zianis and Mencuccini, 2003). The inclusion of height as a predictor variable in allometric biomass estimations is important if the equations are intended to be applied to trees growing at sites other than the one at which the equation was formulated (Jackson et al., 1995; Stewart et al., 1992). Most allometric equations have been developed for mature trees, and relatively few studies have focused on saplings or seedlings (Geudens et al., 2004; Wagner and Ter-Mikaelian, 1999).

The genus Nothofagus occurs in Chile, Argentina, New Zealand, Australia and New Guinea (Veblen et al., 1996). Nothofagus pumilio forests are the most important native forest resource in southern Chile and Argentina (Bartsch and Rapp, 1994; Cuevas, 2002), covering 3400346 ha from $35^{\circ} 35^{\prime} \mathrm{S}$ to $56^{\circ} 00^{\prime} \mathrm{S}$ in Chile and 1526275 ha from $37^{\circ} 30^{\prime} \mathrm{S}$ to $56^{\circ} 00^{\prime} \mathrm{S}$ in Argentina (Bava, 1999; Rosenfeld et al., 2006). The current silvicultural method applied to these forests is the shelterwood cutting (Martinez Pastur et al., 2007; Schmidt et al., 2003). This method involves two main steps, a seed cut and a removal cut. The seed cut is a cutting performed to open the stand sufficiently to promote the establishment and development of natural regeneration. The removal cut is done when natural regeneration is well established to remove the residual canopy of the old stand and to allow the new stand to grow.

Above and below-ground biomass and carbon storage of Nothofagus forests have been partially studied especially at seedlings and saplings stages.

The objectives of this study were to develop allometric equations that enable estimation of total aboveground (foliage; stem and branches) and belowground biomass for natural regeneration of lenga (Nothofagus pumilio) and quantify the amount of biomass and carbon storage in the natural regeneration at different development stages, in a 14-years chronosequence after shelterwood cuts, in the Chilean Patagonia.

\section{MATERIALS AND METHODS}

\subsection{Study area}

This study was carried out in the periods January-February 2006 and January-February 2007, in the estate of "Monte Alto", Province of Ultima Esperanza, Region of Magallanes, Chile, $52^{\circ} 05^{\prime} \mathrm{S}$ and $71^{\circ}$ 42 ' W (Fig. 1). The study area is a continuum of pure old-growth lenga forests managed by shelterwood cuts.

The mean annual temperature is $5{ }^{\circ} \mathrm{C}$ and the annual average precipitation of $596 \mathrm{~mm}$ is homogenously distributed throughout the year (Schmidt et al., 2003). During summer, strong winds are frequent, with gusts attaining $120 \mathrm{~km} \mathrm{~h}^{-1}$ (Caldentey et al., 2001). The topography corresponds to gently undulating hillocks, with maximum slopes of $20 \%$. Soils are derived from glacial drift and volcanic materials with sand-loam textural classes. Soils under Lenga forests can exhibit podzolization, characterized by the presence of $\mathrm{E}$ and $\mathrm{Bhs}$ horizons. The origin of the E horizon is thought to be volcanic ash, altered by eluviation processes (Klein et al., 2008). Rooting systems are mostly concentrated in the first $50 \mathrm{~cm}$ of the profile (Schmidt et al., 2008).

\subsection{Forest stands}

Four adjacent forest stands with natural regeneration at different development stages after shelterwood cuts were selected: two stands that had been subjected to seed cuts three and eight years, respectively, before this study (S3 and S8); and a stand subjected to both a seed cut and a final cut of the residual canopy, 14 and four years, respectively, prior to this study (S14), and one non-intervened primary forest stand $(\mathrm{P})$. We used the four different-aged shelterwood stands as a chronosequence. The forest structure of the stands was characterized by the number of trees ha ${ }^{-1}$ and the basal area of the mature trees (measured at breast height) Table I.

Twenty regeneration inventory plots $\left(2 \mathrm{~m}^{2}\right)$ were systematically distributed in each stand at $20 \mathrm{~m}$ intervals in two parallel transects separated by $60 \mathrm{~m}$. The total plant height, basal diameter (measured at ground level), and number of seedlings (total height $<140 \mathrm{~cm}$ ) and saplings (total height $>140 \mathrm{~cm}, D B H<5 \mathrm{~cm}$ ) (Rebertus and Veblen, 1993) were measured in each plot to determine natural regeneration density, height, basal diameter and height classes distribution, Tables I and II, respectively.

\subsection{Biomass sampling}

A total of 390 seedlings and saplings with basal diameter between 0.1 and $7.1 \mathrm{~cm}$ and total heights ranging from 3 to $365 \mathrm{~cm}$ were destructively sampled from the stands described in Table I. A summary of the descriptive statistics of the sampled seedlings and saplings is presented in Table III. The whole root system of each collected seedling and sapling was excavated. The sandy loam textured soil, and the use of shovels and air at a pressure of 4 to 7 bars (Schmidt et al., 2008), allowed each root system to be extracted nearly intact. The height between the root collar and the top was measured to the nearest $0.1 \mathrm{~cm}$. The basal diameter was measured to the nearest $0.1 \mathrm{~mm}$ using a calliper. Sampled seedlings and saplings were separated at the root-collar in aboveground biomass (foliage, stem and branches) and belowground biomass (including stump and roots). 


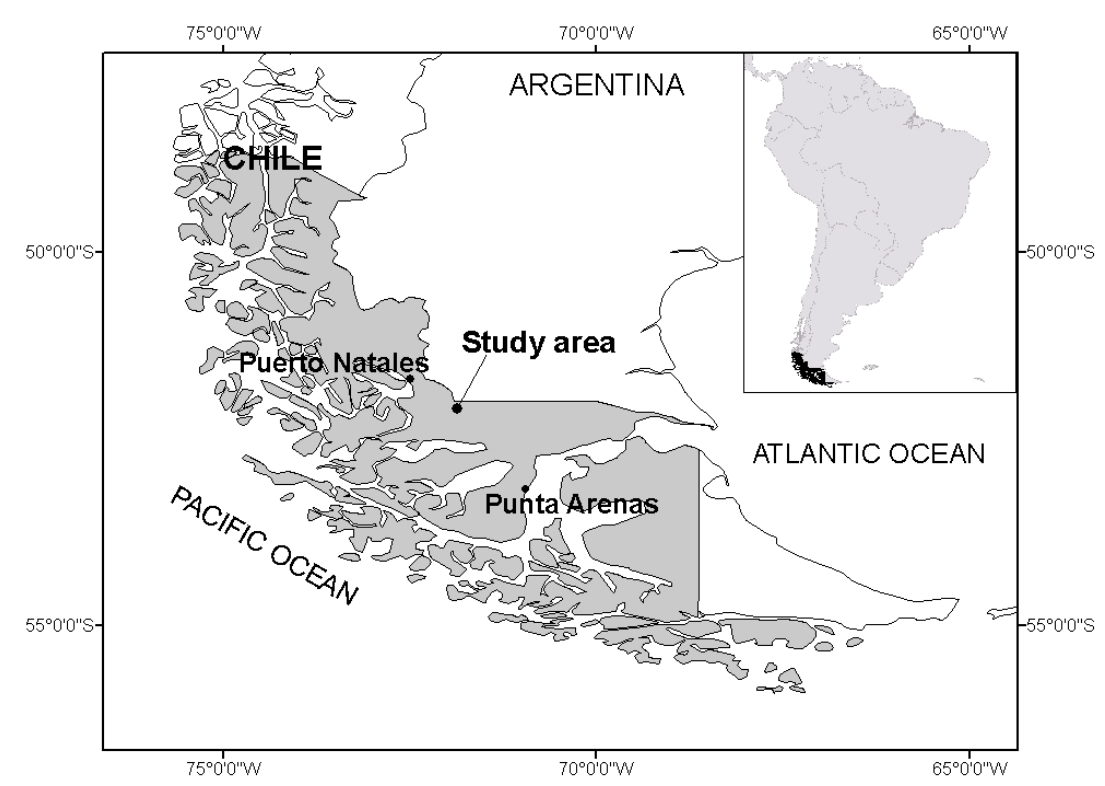

Figure 1. General location of the study area.

Table I. Original and residual forest structure of the forest stands.

\begin{tabular}{|c|c|c|c|c|c|c|c|}
\hline \multirow[b]{2}{*}{ Stand } & \multicolumn{2}{|c|}{ Original structure } & \multicolumn{2}{|c|}{ Residual structure } & \multicolumn{3}{|c|}{ Natural regeneration } \\
\hline & $\begin{array}{c}N \\
\left(\text { trees } \mathrm{ha}^{-1}\right)\end{array}$ & $\begin{array}{c}B A \\
\left(\mathrm{~m}^{2} \mathrm{ha}^{-1}\right)\end{array}$ & $\begin{array}{c}N \\
\left(\text { trees ha }{ }^{-1}\right)\end{array}$ & $\begin{array}{c}B A \\
\left(\mathrm{~m}^{2} \mathrm{ha}^{-1}\right)\end{array}$ & $\begin{array}{c}R D \\
\left(\text { stems ha }^{-1}\right)\end{array}$ & $\begin{array}{c}H \\
(\mathrm{~cm})\end{array}$ & $\begin{array}{c}B D \\
(\mathrm{~mm})\end{array}$ \\
\hline$\overline{\mathrm{P}}$ & 845 & 64.0 & 845 & 64.0 & 490,500 & 7.5 & 1.5 \\
\hline S3 & 630 & 61.4 & 222 & 29.3 & 439,500 & 18.1 & 3.6 \\
\hline S8 & 400 & 69.9 & 163 & 37.8 & 301,500 & 31.4 & 4.9 \\
\hline S14 & 415 & 74.8 & 7 & 4.7 & 287,250 & 97.1 & 13.2 \\
\hline
\end{tabular}

$N$ is tree density; $B A$ is basal area; $R D$ is natural regeneration density; $H$ is the average height of the natural regeneration; $B D$ is the average basal diameter of the natural regeneration.

The samples had been oven-dried to a constant weight at $65^{\circ} \mathrm{C}$ and weighed on an electronic scale to the nearest $0.01 \mathrm{~g}$. Carbon content for foliage $(n=10)$ and stem $(n=10)$ was measured by dry combustion using an EA 3000 elementary analyzer following DIN ISO 10694.

\subsection{Regression analysis}

Different models for estimating total-tree and tree-component biomass were used in former studies. The commonly used mathematical model is the allometric equation corresponding to the following power form:

$$
Y=a X^{\mathrm{b}}
$$

where $Y$ is the total oven-dry biomass or one of its components $(\mathrm{kg}), X$ is a seedling and/or sapling dimension variable - basal diameter $(D$ in $\mathrm{cm})$, height $(H$ in $\mathrm{cm}), D^{2}\left(\mathrm{~cm}^{2}\right)$ or $D^{2} H\left(\mathrm{~cm}^{3}\right) ; a$ and $b$ are model parameters (Geudens et al., 2004; Parresol, 1999). This equation describes a curved line passing through the origin and is commonly used to describe the relation between tree biomass and basal diameter. It also provides a good balance of accurate predictions and low data requirements (Ter-Mikaelian and Korzukhin, 1997; Ter-Mikaelian and Parker, 2000). The parameters of the equation were estimated using least squares procedures after the transformation of the non-linear equation into a linear equation, applying logarithms to both sides of the equation (Cole and Ewel, 2006; Geudens et al., 2004; Parresol, 1999). The log-log regression takes the form:

$$
\ln Y=\ln a+b \ln X+\varepsilon .
$$

Since users need predictions in arithmetic units rather than logarithmic units, the best-fit equations were back-transformed to their original form. Reverse transformation on an arithmetic scale produces a systematic underestimation of the dependent variable (Baskerville, 1972; Ter-Mikaelian and Parker, 2000). Several procedures for correcting bias in logarithmic regression estimates have been reported. In this study, the logarithmic bias correction term added to the intercept before back-transformation was:

$$
C F=S E E^{2} / 2
$$

where $C F$ is the correction factor and $S E E$ is the standard error of the estimation (Baskerville, 1972; Zianis and Mencuccini, 2003). The selection of the best models was based on the highest coefficient of adjusted determination for logarithmic regression $\left(R_{\mathrm{aj}}^{2}\right)$, the lowest standard error of estimate (SEE), and the lowest Furnival's index $(F I)$ (Parresol, 1999). The coefficient of adjusted determination is calculated as:

$$
R_{\mathrm{aj}}^{2}=1-(R S S / T S S)
$$


Table II. Regeneration density $\left(\right.$ stems $\left.\mathrm{ha}^{-1}\right)$ distributed in height classes $(\mathrm{cm})$ in the forest stands.

\begin{tabular}{lcccc}
\hline $\begin{array}{l}\text { Height classes } \\
(\mathrm{cm})\end{array}$ & $\begin{array}{c}P \\
\left(\text { stems ha }^{-1}\right)\end{array}$ & $\begin{array}{c}\text { S3 } \\
\left(\text { stems ha }^{-1}\right)\end{array}$ & $\begin{array}{c}\text { S } \\
\left(\text { stems ha }^{-1}\right)\end{array}$ & $\begin{array}{c}\text { S14 } \\
\left(\text { stems ha }^{-1}\right)\end{array}$ \\
\hline $0-10$ & 418.500 & 140.000 & 82.500 & 7.250 \\
$11-30$ & 54.500 & 225.750 & 126.500 & 32.000 \\
$31-50$ & 4.750 & 64.000 & 26.500 & 41.000 \\
$51-100$ & 7.500 & 9.250 & 47.000 & 95.750 \\
$>101$ & 5.250 & 500 & 19.000 & 111.250 \\
Total plants & 490.500 & 439.500 & 301.500 & 287.250 \\
\hline
\end{tabular}

Table III. General statistics for variables used in the development of allometric biomass equations for Nothofagus pumilio natural regeneration $(N=390)$.

\begin{tabular}{llllllll}
\hline & $\begin{array}{l}B D \\
(\mathrm{~mm})\end{array}$ & $\begin{array}{l}H \\
(\mathrm{~cm})\end{array}$ & $\begin{array}{l}T B \\
(\mathrm{~g})\end{array}$ & $\begin{array}{l}A B \\
(\mathrm{~g})\end{array}$ & $\begin{array}{l}F B \\
(\mathrm{~g})\end{array}$ & $\begin{array}{l}S B B \\
(\mathrm{~g})\end{array}$ \\
\hline Min. & 1.0 & 2.5 & 0.23 & 0.06 & 0.01 & 0.05 & 0.03 \\
Max. & 72.0 & 365.0 & 2623.50 & 1838.52 & 364.12 & 1545.10 \\
Mean & 8.6 & 54.9 & 75.74 & 51.20 & 7.22 & 44.74 & 785.00 \\
Standard error & 0.4 & 2.8 & 13.04 & 9.70 & 1.22 & 8.66 \\
\hline
\end{tabular}

$B D$ is the basal diameter; $\mathrm{H}$ is height; $T B$ is total biomass (dry weight); $A B$ is aboveground biomass; $F B$ is foliage biomass; $S B B$ is stem + branches biomass and $B B$ is belowground biomass.

$$
\begin{aligned}
& R S S=\sum_{i=1}^{n}\left(Y_{\mathrm{i}}-\hat{Y}_{\mathrm{i}}\right)^{2} \\
& T S S=\sum_{i=1}^{n}\left(Y_{\mathrm{i}}-\bar{Y}_{\mathrm{i}}\right)^{2}
\end{aligned}
$$

were $\hat{Y}_{\mathrm{i}}$ is the estimated biomass, $Y_{\mathrm{i}}$ is the observed biomass and $\bar{Y}$ is the arithmetic mean of $Y$. The standard error of estimate is calculated as:

$$
S E E=\sqrt{R S S /(n-p)}
$$

where $n$ is the number of observations and $p$ is the number of model parameters. The general formula for Furnival's index $(F I)$ is:

$$
F I=\left[f^{\prime}(Y)\right] \times R M S E
$$

where $f^{\prime}(Y)$ is the derivative of the dependent variable, the brackets represent the geometric mean, and RMSE is the root mean square error of the fitted equation (Parresol, 1999). The mean percent standard error $\bar{S}(\%)$ between the predictions and the raw data was used to assess the performance of the different models. This statistic indicates the size of the error as a percentage of the mean of the distribution of $Y_{i}$. The expected value of $\bar{S}(\%)$ is 0 (Parresol, 1999; Zianis and Mencuccini, 2003). $\bar{S}(\%)$ is calculated as the average of the differences between observed and predicted values divided by observed values:

$$
\bar{S}(\%)=\frac{100}{n} \sum_{i=1}^{n}\left|Y_{\mathrm{i}}-\hat{Y}_{\mathrm{i}}\right| / \hat{Y}_{\mathrm{i}}
$$

where $Y_{\mathrm{i}}$ are the observed biomass values and $\hat{Y}_{\mathrm{i}}$ are the predicted biomass values. Durbin-Watson statistics were used as quality indicators of the fitted functions to test for correlated residuals and the Kolmogorov-Smirnoff test of normal distribution of the residuals. Outliers were identified and removed from the data set using scatterplot analysis and studentized residual threshold values $>3.0$. Significance levels of 0.05 were used for all tests. Statistical and regression analyses were carried out using SPSS 11.3 (SPSS Inc., Chicago,
USA). The best-fit biomass equations were applied to the regeneration inventory data to estimate biomass (dry weight) accumulation $\left(\mathrm{Mg} \mathrm{ha}^{-1}\right)$ and the carbon storage $\left(\mathrm{Mg} \mathrm{ha}^{-1}\right)$ across the 14-years chronosequence.

\section{RESULTS AND DISCUSSION}

\subsection{Regression equations}

Scatterplots of the data indicated that biomass values (aboveground, belowground, and total) were non-linearly related to basal diameter and plant height, and that they exhibit heteroscedasticity (Fig. 2). This coincides with the tendencies reported by Parresol (1999).

The data were transformed using the logarithmic function and the least squares method was applied to estimate model parameters. The results are presented in Table IV.

All the regression analyses showed a level of significance of $P<0.01, R_{\text {aj }}^{2}$ values above $0.90\left(R_{\text {aj }}^{2}\right.$ given for $\log$ transformed variables), a normal distribution, and independency of the residuals. Scatterplots of the residuals did not show patterns of increasing error variance with increasing predicted values. Basal diameter was the most important variable and explained more than $95 \%$ of the variability of the different biomass compartments, consistent with the results reported by Williams and Mc Clenahen (1984) and Ter-Mikaelian and Parker (1999).

Height by itself was a good predictor of biomass with $R_{\mathrm{aj}}^{2}$ values above 0.90 , but the addition of $H$ as a second variable slightly improved the predictions. The correlation between $D$ and $H$ was $0.95(P<0.001)$ and explains the low gains in prediction when $H$ is included in the models (multicolinearity). Compared with $D$ or $D^{2}$ only equations, $D-H$ and $D^{2} H$ 


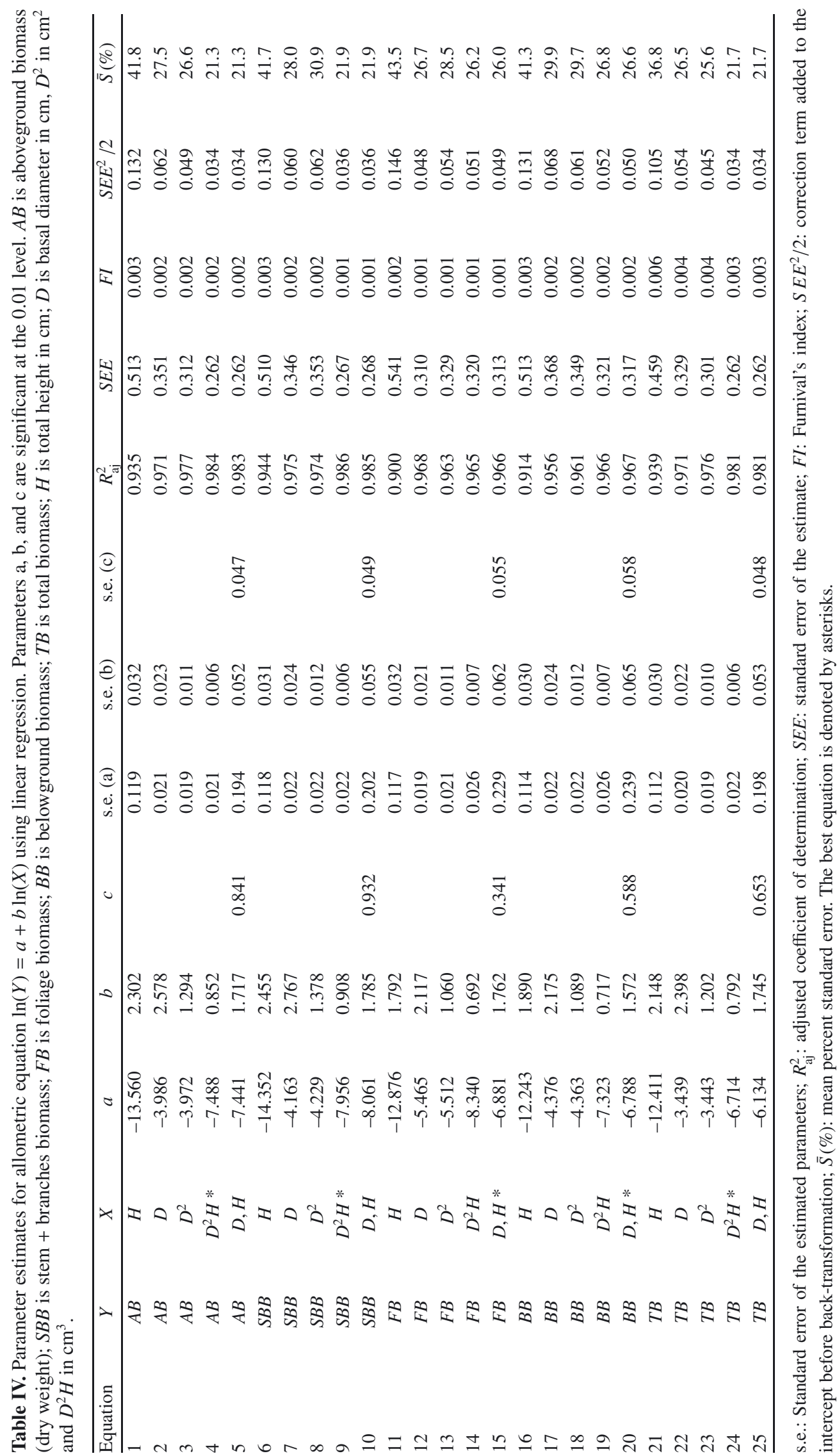




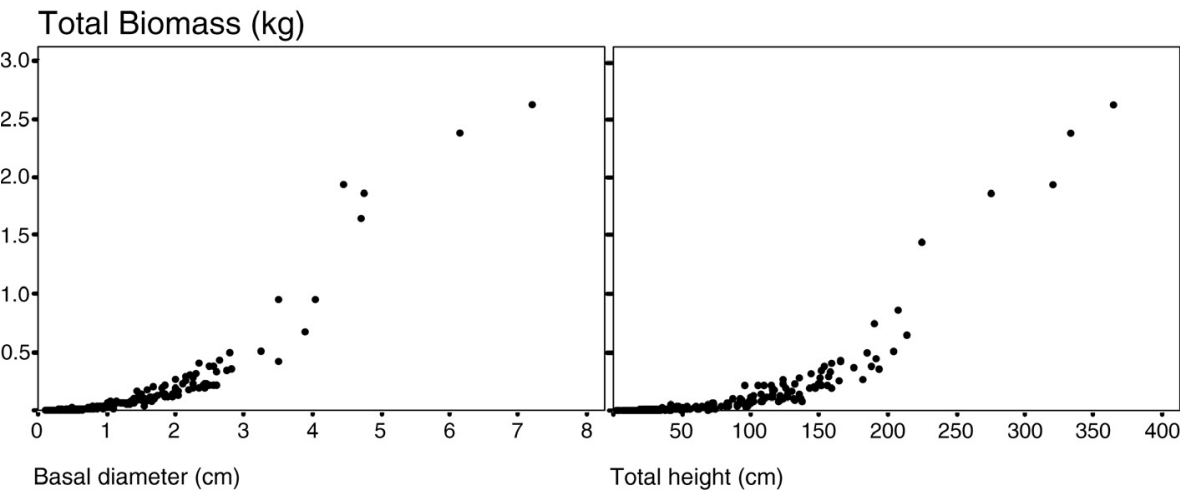

Figure 2. Scatterplots of basal diameter $(\mathrm{cm})$ and total height $(\mathrm{cm})$ vs. total biomass (dry weight) $(\mathrm{kg})$ of the natural regeneration $(n=390)$.

combined equations increased $R_{\mathrm{aj}}^{2}$ values by less than $1.5 \%$ for the different biomass components. A similar contribution of $H$ was reported by Williams and Mc Clenahen (1984) for different hardwood tree seedlings and saplings and by Wagner and Ter-Mikaelian (1999) for coniferous tree seedlings. In contrast with mature trees, simple measurements of height are easier to take in the field than basal diameter measurements, especially when natural regeneration is dense.

Because $D$ alone is such a good biomass predictor, only marginal improvement can be expected by adding $H$ as a second independent variable. In this study, the addition of $H$ contributed to decreases in the SEE for the different biomass compartments and to decreases in the mean percent standard error by $6.2 \%$ for the aboveground biomass, $3.1 \%$ to $3.3 \%$ for the belowground biomass, and $4.8 \%$ for the total biomass. Also the incorporation of height has the advantage of increasing the equation's potential applicability to different sites (Cole and Ewel, 2006; Jackson et al., 1995).

The best-fit equation for total biomass based on combinations of basal diameter $(D)$ and total height $(H)$ as independent variables in the form $D^{2} H$ (Eq. (24); Tab. IV) presented, after arithmetical transformation, an adjusted $R^{2}=0.94$, a $S E E=0.068$, and a $\bar{S}(\%)=21.7 \%$. The equation takes the following power form:

$$
Y=0.00125625 \times\left(D^{2} H\right)^{0.792} .
$$

Aboveground biomass was best predicted by using the combination of basal diameter $(D)$ and total height $(H)$ as independent variables in the form $D^{2} H$ (Eq. (4); Tab. IV) and presented, after arithmetical transformation, an adjusted $R^{2}=$ 0.89 , a $S E E=0.068$, and a $\bar{S}(\%)=21.3 \%$. The equation takes the following power form:

$$
Y=0.00057926 \times\left(D^{2} H\right)^{0.852} .
$$

The stem and branches biomass was best predicted by using the combination of basal diameter $(D)$ and total height $(H)$ as independent variables in the form $D^{2} H$ (Eq. (9); Tab. IV) and presented, after arithmetical transformation, an adjusted $R^{2}=$ 0.80 , a $S E E=0.081$, and a $\bar{S}(\%)=21.9 \%$. The equation takes the following power form:

$$
Y=0.00035044 \times\left(D^{2} H\right)^{0.908} .
$$

This is consistent with Williams and McClenahen (1984), who suggested that the combination of basal diameter and total height in the form $D^{2} H$ provides the best independent variable for predicting aboveground biomass of seedlings and saplings.

Foliage biomass was best predicted by using basal diameter $(D)$ and total height $(H)$ as independent variables (Eq. (15); Tab. IV) and presented, after arithmetical transformation, an adjusted $R^{2}=0.84$, a $S E E=0.010$, and a $\bar{S}(\%)=26.6 \%$. The equation takes the following power form:

$$
Y=0.0010272 \times D^{1.762} \times H^{0.341} .
$$

Belowground biomass was best predicted by using $D$ and $H$ as independent variables (Eq. (20); Tab. IV) and presented, after arithmetical transformation, an adjusted $R^{2}=0.95$, a $S E E=$ 0.016 , and a $\bar{S}(\%)=26.6 \%$.

The equation takes the following power form:

$$
Y=0.001185459 \times D^{1.572} \times H^{0.588}
$$

Furnival's index confirmed the observed trend for the five equations (Tab. IV). For the five selected equations, the coefficient of Durbin-Watson, ranging between 1.853 and 1.987 , suggests the independency of the residuals, justifying the choice of the models. Furthermore, the results of the Kolmogorov-Smirnoff test proved the normality of the distribution of the residuals, and the analysis of the scatterplots did not show patterns of increasing error variance when increasing the independent values.

The $\bar{S}(\%)$ of the selected equations, ranging between $21.3 \%$ and $26.6 \%$, was within the range reported by Pastor et al. (1984) and Zianis and Mencuccini (2003) for regressions (for mature trees) developed from field data.

\subsection{Above-belowground biomass}

The collected biomass of the total set of sample seedlings and saplings used for the regression analysis $(n=390)$ reached $28.4 \mathrm{~kg}$. It was dominated by aboveground biomass with $19.6 \mathrm{~kg}(68.9 \%)$, while belowground biomass reached $8.8 \mathrm{~kg}$ $(31.1 \%)$. Foliage biomass represented $13.6 \%(2.7 \mathrm{~kg})$ and stem and branches $86.4 \%(16.9 \mathrm{~kg})$ of aboveground biomass. The 


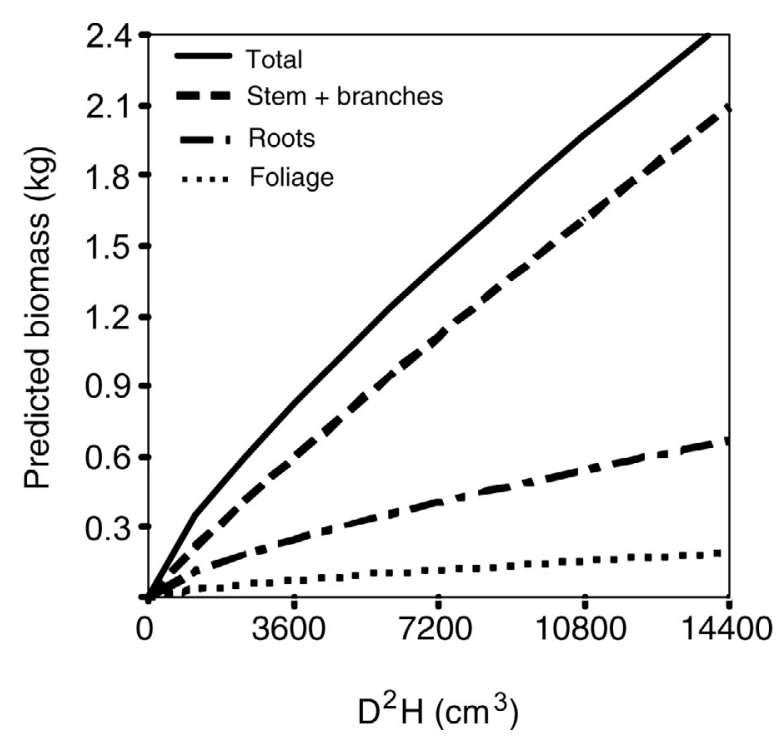

Figure 3. Predictions of total, foliage, stem + branches, and roots biomass (dry weight) related to $D^{2} H$ of the natural regeneration.

estimated biomass for the same sample, using the selected biomass equations, was $27.3 \mathrm{~kg}$ for total biomass, $18.9 \mathrm{~kg}$ for aboveground biomass, and $8.7 \mathrm{~kg}$ for belowground biomass. This means an underestimation of $3.9 \%, 3.6 \%$, and $1.2 \%$ respectively. Foliage biomass reached $2.6 \mathrm{~kg}$ and stem and branches biomass $17.4 \mathrm{~kg}$. This means an underestimation of $3.7 \%$ for foliage biomass and an overestimation of $2.9 \%$ for stem and branches biomass. The difference between total biomass and the sum of above and belowground estimations was $1.1 \%$, while the difference of aboveground biomass and the sum of foliage and stem and branches biomass was 5.5\%. Similar tendencies between single-equation and additive estimations were described by Cienciala et al. (2006) for Fagus sylvatica. Aboveground to belowground biomass ratios tended to increase with increasing tree size, ranging from 0.6 to 3.0. These ratios tendencies are comparable with Bartsch and Rapp (1994) values, reporting aboveground to belowground ratios from 0.7 to 1.0 for 5-year old lenga seedlings in Argentina. Stem and branches to foliage biomass ratios exhibited similar tendencies with increasing tree size, ranging from 0.7 to 10.7 (Fig. 3). The percentage of foliage biomass decreased with increasing stem basal diameter, consistent with the results reported by Haase and Haase (1995).

\subsection{Natural regeneration stand biomass}

The natural regeneration stand biomass estimated using the selected allometric equations for the different components varied from $0.9 \mathrm{Mg} \mathrm{ha}^{-1}\left(0.5 \mathrm{Mg} \mathrm{ha}^{-1}\right.$ above and $0.4 \mathrm{Mg} \mathrm{ha}^{-1}$ belowground) in the primary forest to $1.3 \mathrm{Mg} \mathrm{ha}^{-1}\left(0.7 \mathrm{Mg} \mathrm{ha}^{-1}\right.$ above and $0.6 \mathrm{Mg} \mathrm{ha}^{-1}$ belowground) three years after the seed cut. Eight years after the seed cut the biomass increased to $3.2 \mathrm{Mg} \mathrm{ha}^{-1}$ (2.0 Mg ha ${ }^{-1}$ above and $1.2 \mathrm{Mg} \mathrm{ha}^{-1}$ belowground) while 14 years after the seed cut the natural regeneration biomass went up to $19.5 \mathrm{Mg} \mathrm{ha}^{-1}\left(13.6 \mathrm{Mg} \mathrm{ha}^{-1}\right.$ above

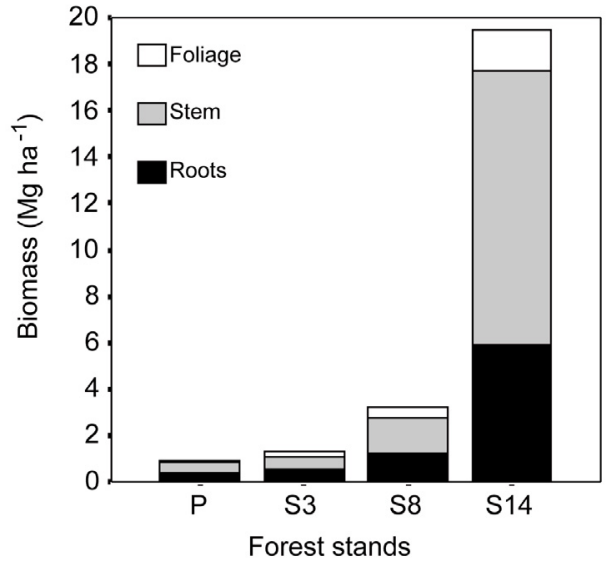

Figure 4. Foliage, stem + branches, and root biomass (dry weight) storage $\left(\mathrm{Mg} \mathrm{ha}^{-1}\right)$ in forest stands.

and 5.9 $\mathrm{Mg} \mathrm{ha}^{-1}$ belowground). A significant increase in the natural regeneration biomass was observed in the 14-years chronosequence period $(F=21.0 ; P=0.000)$. The proportion of biomass allocated to stem and branches increased with tree size. This produced an increase in the above/belowground biomass ratio, from 1.5 in the primary forest to $2.3,14$ years after the seed cut (Fig. 4). Similar tendencies were reported by Cole and Ewel (2006) for small tropical trees.

\subsection{Carbon storage}

Carbon concentrations in foliage and stem and branches were $47.5 \%(S E=0.5 \%)$ and $50.3 \%(S E=0.5 \%)$ respectively. Bartsch and Rapp (1994) reported a foliage carbon content between $42.2 \%$ and $46.8 \%$ for lenga seedlings growing in Argentina. Weber (2001) reported carbon concentrations of $47.9 \%$ for foliage biomass, $50.2 \%$ for bark, and $47.3 \%$ for sapwood for mature lenga trees growing in Tierra del Fuego, Argentina. The high contents of carbon in stem and roots were due to the fact that we did not separate the bark from the sapwood, and bark exhibits more carbon content than sapwood. We assumed the same carbon values for roots than for stem and branches. Across the 14-years chronosequence, the carbon storage in the natural regeneration increased from $0.5 \mathrm{Mg} \mathrm{ha}^{-1}\left(0.3 \mathrm{Mg} \mathrm{ha}^{-1}\right.$ above and $0.2 \mathrm{Mg} \mathrm{ha}^{-1}$ belowground) in the primary forest to $9.8 \mathrm{Mg} \mathrm{ha}^{-1}$ (6.8 $\mathrm{Mg} \mathrm{ha}^{-1}$ above and $3.0 \mathrm{Mg} \mathrm{ha}^{-1}$ belowground) 14 years after the shelterwood cuts. Carbon storage is strongly related to biomass allocation dynamics in the natural regeneration.

The allometric biomass equations for Nothofagus pumilio seedlings and saplings presented in this paper are only valid within the range of stem heights and basal diameters used for the calibration of the equations. Differences in growing conditions such as available light, water or nutrients, result in different anatomical responses of seedlings (Bloomberg et al., 2008). Due to this, the validity under different growth conditions or in other regions should be tested before general application, especially in forests with browsing damages, where the ratio of seedling height to seedling basal diameter is affected. 


\section{CONCLUSIONS}

This study confirmed the existence of a strong relationship between basal diameter and biomass compartments (foliage, stem and branches (aboveground), roots (belowground), and total biomass) in seedlings and saplings. Height was also a good predictor of biomass, and its addition as a second independent variable slightly improved the equations. These allometric equations provide a useful tool for rapid estimation of the biomass of Nothofagus pumilio natural regeneration growing in natural and managed lenga forests in the Chilean Patagonia. Biomass estimation and its allocation dynamics in the different compartments of the natural regeneration in early development stages allow the assessment of net primary productivity of the regeneration, responses to silvicultural interventions such as seed cuts, and development of silvicultural strategies to promote its establishment and successful development.

Natural regeneration exhibits considerable biomass buildup and carbon storage after the opening of the canopy using shelterwood cuts and especially after the final cut of the residual canopy. These equations are species specific and the validity under different growth conditions or in other regions should be tested before general application, especially in forests with browsing damages.

Acknowledgements: We thank the companies "Forestal y Ganadera Monte Alto Ltda". and "Salfa Corp". for allowing us to use their forests. We also thanks the reviewers for their important contributions and suggestions to this article. This study was carried out under a cooperative project between the Universidad de Chile and the Wald-Zentrum of the Westfälische Wilhelms-Universität Münster, supported by the Programme Alban, the European Union Programme of High Level Scholarships for Latin America, scholarship No. E05D055502CL.

\section{REFERENCES}

Baskerville G.L., 1972. Use of logarithmic regression in the estimation of plant biomass. Can. J. For. Res. 2: 49-53.

Bartsch N. and Rapp C., 1994. Naturverjüngung von Nothofagus pumilio im Lochhieb. Verjüngungsökologische Untersuchungen im nordpatagonischen Bergwald Argentiniens. Forstarchiv 65:119-130.

Bava J., 1999. Los bosques de lenga en Argentina. In: Donoso C. and Lara A. (Eds.), Silvicultura de los bosques nativos de Chile, Editorial universitaria, Santiago de Chile, pp. 273-296.

Bloomberg M., Mason E., and Jarvis P., 2008. Predicting seedling biomass of radiata pine from allometric variables. New For. 36: 103114.

Caldentey J., Ibarra M., and Hernández P., 2001. Litter fluxes and decomposition in Nothofagus pumilio stands in the region of Magallanes, Chile. For. Ecol. Manage. 148: 145-157.

Cienciala E., Cerny M., Tatarinov F., and Apltauer J., 2006. Biomass functions applicable to Scots pine. Trees 20: 483-495.

Cole T.G. and Ewel J.J., 2006. Allometric equations for four valuable tropical tree species. For. Ecol. Manage. 229: 351-360.

Cuevas J.G., 2002. Episodic regeneration at the Nothofagus pumilio alpine timberline in Tierra del Fuego, Chile. J. Ecol. 90, 52-60.

Geudens G., Staelens J., Kint V., Goris R., and Lust N., 2004. Allometric biomass equations for Scots pine (Pinus sylvestris L.) seedlings dur- ing the first years of establishment in dense natural regeneration. Ann. For. Sci. 61: 653-659.

Haase R. and Haase P., 1995. Above-ground biomass estimates for invasive trees and shrubs in the Pantanal of Mato Grosso, Brazil. For. Ecol. Manage. 73: 29-35.

Jackson N.A., Griffiths H., and Zeroni M., 1995. Above-ground biomass of seedling and semi-mature Sesbania sesban, a multi-purpose tree species, estimated using allometric regressions. Agrofor. Syst. 29: 103-112.

Klein D., Fuentes J.P., Schmidt A., Schmidt H., and Schulte A., 2008. Soil organic $\mathrm{C}$ as affected by silvicultural and exploitative interventions in Nothofagus pumilio forests of the Chilean Patagonia. For. Ecol. Manage. 255: 3549-3555.

Martínez P.G., Lencinas M.V., Peri P.L., and Arena M., 2007. Photosynthetic plasticity of Nothofagus pumilio seedlings to light intensity and soil moisture. For. Ecol. Manage. 243: 274-282.

Parresol B., 1999. Assessing tree and stand biomass: A review with examples and critical comparisons. For. Sci. 45: 573-593.

Parresol B., 2001. Additivity of nonlinear biomass equations. Can. J. For. Res. 31: 865-878.

Pastor J., Aber J.D., and Melillo J.M., 1984. Biomass prediction using generalized allometric regressions for some northeast tree species. For. Ecol. Manage. 7: 265-274.

Rebertus A.J. and Veblen T.T., 1993. Structure and tree-fall gaps dynamics of old-growth Nothofagus forest in Tierra del Fuego, Argentina. J. Veg. Sci. 4: 641-654.

Rosenfeld J.M., Navarro Cerrillo R.M., and Guzman A.J.R., 2006. Regeneration of Nothofagus pumilio [Poepp. Et Endl.] Krasser forests after five years of seed tree cutting. J. Environ. Manage. 78: $44-51$.

Schmidt H., Cruz G., Promis A., and Alvarez M., 2003. Transformación de los bosques de lenga vírgenes e intervenidos a bosques manejados. Universidad de Chile, Facultad de Ciencias Forestales, Publicaciones miscelaneas forestales No. 14, Santiago, Chile, 60 p.

Schmidt A., Klein D., Leuthold F., Schmidt H., and Schulte A., 2008. Anteil der Wurzelbiomasse an der Gesamtbaumbiomasse eines Lenga (Nothofagus pumilio) Naturwaldes im chilenischen Teil Patagoniens. Forstarchiv 79: 55-59.

Stewart J.L., Dunsdon A.J., Hellin J.J., and Hughes C.E., 1992. Wood biomass estimation of central american dry zone species. Tropical forestry papers No. 26, Oxford/UK, Oxford Forestry Institute.

Ter-Mikaelian M. and Korzukhin M., 1997. Biomass equations for sixtyfive North American tree species. For. Ecol. Manage. 97: 1-24.

Ter-Mikaelian M. and Parker W., 2000. Estimating biomass of white spruce seedlings with vertical photo imagery. New For. 20: 145-162.

Veblen T.T., Hill R.S., and Read J., 1996. The ecology and biogeography of Nothofagus forests, Yale University Press, New Haven, 403 p.

Verwijst T., 1991. Logarithmic transformation in biomass estimation procedures: violation of the linearity assumption in regression analysis. Biomass Bioenergy 1: 175-180.

Wagner R.G. and Ter-Mikaelian M.T., 1999. Comparison of biomass component equations for four species of northern coniferous tree seedlings. Ann. For. Sci. 56: 193-199.

Weber M., 2001. Kohlenstoffspeicherung in Lenga-(Nothofagus pumilio) Primärwäldern Feuerlands und Auswirkungen ihrer Überführung in Wirtschaftswald auf den C-Haushalt, Kessel, Remagen, 119 p.

Williams R.A. and Mc Clenahen J.R., 1984. Biomass prediction equation for seedlings, sprouts, and saplings of ten central hardwood species. For. Sci. 30: 523-527.

Zianis D. and Mencuccini M., 2003. Aboveground biomass relationships for beech (Fagus moesiaca Cz.) trees in Vernio Mountain, Northern Greece, and generalised equations for Fagus sp. Ann. For. Sci. 60: $439-448$. 